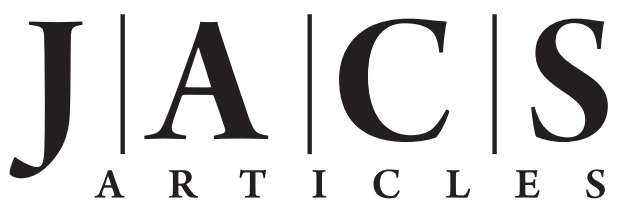

Published on Web 06/01/2009

\title{
Design Strategies for Ratiometric Chemosensors: Modulation of Excitation Energy Transfer at the Energy Donor Site
}

\author{
Ruslan Guliyev, ${ }^{\dagger, \ddagger}$ Ali Coskun, ${ }^{\dagger}$ and Engin U. Akkaya*,‡ \\ Department of Chemistry, Middle East Technical University, 06531, Ankara, Turkey, and \\ Department of Chemistry and UNAM-Materials Science and Nanotechnology Institute, \\ Bilkent University, 06800 Ankara, Turkey
}

Received April 1, 2009; E-mail: eua@fen.bilkent.edu.tr

\begin{abstract}
Excitation energy transfer, when coupled to an ion-modulated ICT chromophore, creates novel opportunities in sensing. The direction of energy transfer and the point of ICT modulation can be varied as desired. In our previous work, we have shown that energy transfer efficiency between two energetically coupled fluorophores will be altered by the metal ion binding to the ICT chromophore carrying a ligand. There are two beneficial results: increased pseudo-Stokes shift and expanded dynamic range. Here, we explored the consequences of the modulation of energy transfer efficiency at the energy donor site, in a molecular design which has an ICT type metal ion-sensitive chromophore placed as the energy donor in the dyad. Clear advantages emerge compared to the acceptor site modulation: unaltered emission wavelength in the red end of the visible spectrum, while keeping a large Stokes shift and the ratiometric character.
\end{abstract}

\section{Introduction}

Fluorescent chemosensor research of the last few decades have been both very instructive and productive. ${ }^{1}$ Especially, work targeting ion sensing in cellular media ${ }^{2}$ has significantly improved our understanding of biochemical processes involved in healthy and pathological states. While a large number of chemosensors of practical utility have been developed based on previously established principles, a few research groups push frontiers of chemosensor design by proposing new sensing methodologies. Successful chemosensors make use of a large number of different photophysical phenomena such as PET, ${ }^{3}$ ICT, ${ }^{4}$ excimer formation, ${ }^{5}$ excited state reactions, ${ }^{6}$ excitation

${ }^{\dagger}$ Middle East Technical University.

Bilkent University.

(1) (a) de Silva, A. P.; Fox, D. B.; Huxley, A. J. M.; Moody, T. S. Coord. Chem. Rev. 2000, 205, 41-57. (b) Wright, A. T.; Anslyn, E. V. Chem. Soc. Rev. 2006, 35, 14-28. (c) de Silva, A. P.; Gunaratne, H. Q. N.; Gunnlaugsson, T.; Huxley, A. J. M.; McCoy, C. P.; Rademacher, J. T. Rice, T. E. Chem. Rev. 1997, 97, 1515-1566. (d) de Silva, A. P.; Uchiyama, S. Nat. Nanotechnol. 2007, 2, 399-410. (e) Czarnik, A. W Acc. Chem. Res. 1994, 27, 302-308. (f) de Silva, A. P.; Gunaratne, H. Q. N.; Habibjiwan, J. L.; McCoy, C. P.; Rice, T. E.; Soumillion, J. P. Angew. Chem., Int. Ed. 1995, 34, 1728-1731. (g) Arnendola, V.; Esteban-Gomez, D.; Fabbrizzi, L.; Licchelli, M. Acc. Chem. Res. 2006, 39, 343-353. (h) Arnendola, V.; Bonizzoni, M.; Esteban-Gomez, D.; Fabbrizzi, L.; Licchelli, M.; Sancenon, F.; Taglietti, A. Coord. Chem. Rev. 2006, 250, 1451-1470. (i) Martinez-Manez, R.; Sancenon, F. Coord. Chem. Rev. 2006, 250, 3081-3093. (j) Martinez-Manez, R.; Sancenon, F. Chem. Rev. 2003, 103, 4419-4476.

(2) (a) Zhang, J.; Campbell, R. E.; Ting, A. Y.; Tsien, R. Y. Nat. Rev. Cell Mol. Biol. 2002, 3, 906-918. (b) Haugland, R. P. Intracelular cellular probes. In The Handbook-A guide to fluorescent probes and labeling technologies, 10th ed.; Invitrogen Corp.: Carlsbad, CA, 2005.

(3) (a) Bissell, R. A.; Desilva, A. P.; Gunaratne, H. Q. N.; Lynch, P. L. M. Maguire, G. E. M.; McCoy, C. P.; Sandanayake, K. R. A. S. Top. Curr. Chem. 1993, 168, 228-264. (b) Bissell, R. A.; Desilva, A. P.; Gunaratne, H. Q. N.; Lynch, P. L. M.; Maguire, G. E. M.; Sandanayake, K. R. A. S. Chem. Soc. Rev. 1992, 21, 187-195. energy transfer, ${ }^{7}$ etc. In addition, supramolecular associations of fluorophores with other molecules were exploited toward molecular design of chemosensors. ${ }^{8}$ A particularly useful subclass of fluorescent chemosensors are ratiometric ones. Using these chemosensors, it is possible to compensate for local

(4) (a) Valeur, B.; Leray, I. Inorg. Chem. Acta. 2007, 360, 765-774. (b) Valeur, B.; Leray, I. Coord. Chem. Rev. 2000, 205, 3-40. (c) Yuan, M.; Li, Y.; Li, J.; Liu, X.; Lv, J.; Xu, J.; Liu, H.; Wang, S.; Zhu, D. Org. Lett. 2007, 9, 2313-2316. (d) Yuan, M.; Zhou, W.; Liu, X.; Zhu, M.; Li, J.; Yin, X.; Zheng, H.; Zuo, Z.; Ouyang, C.; Liu, H.; Li, Y.; Zhu, D. J. Org. Chem. 2008, 73, 5008-5014.

(5) (a) Cho, H. K.; Lee, D. H.; Hong, J. I. Chem. Commun. 2005, 16901692. (b) Lee, H. N.; Xu, Z.; Kim, S. K.; Swamy, K. M. K.; Kim, Y.; Kim, S.-J.; Yoon, J. J. Am. Chem. Soc. 2007, 129, 3828-3829. (c) Takashi, J.; Kazuhiko, I.; Tomiyasu, K. J. Chem. Soc., Chem. Commun. 1992, 49, 9-501. (d) Shiraishi, Y.; Maehara, H.; Ishizumi, K.; Hirai, T. Org. Lett. 2007, 9, 3125. (e) Fages, F.; Bodenant, B.; Weil, T. J. Org. Chem. 1996, 61, 3956-3961. (f) Parker, D.; Williams, J. A. G. J. Chem. Soc., Perkin Trans. 2 1995, 1305. (g) Aoki, I.; Kawabata, H; Nakashima, K.; Shinkai, S. J. Chem. Soc., Chem. Commun. 1991, 1771. (h) Nishizawa, S.; Kaneda, H.; Uchida, T.; Teramae, N. J. Chem. Soc., Perkin Trans. 1998, 2, 2325-2328.

(6) (a) Klymchenko, A. S.; Demchenko, A. P. J. Am. Chem. Soc. 2002, 124, 12372-12379. (b) Seo, J.; Kim, S.; Park, S. Y. J. Am. Chem. Soc. 2004, 126, 11154-11155.

(7) (a) Coskun, A.; Akkaya, E. U. J. Am. Chem. Soc. 2005, 127, 1046410465. (b) Coskun, A.; Akkaya, E. U. J. Am. Chem. Soc. 2006, 128, 14474-14475. (c) Lin, W. Y.; Yuan, L.; Cao, X. W. Tetrahedron Lett. 2008, 49, 6585-6588. (d) Lee, S. Y.; Kim, H. J.; Wu, J. S.; No, K.; Kim, J. S. Tetrahedron Lett. 2008, 49, 6141-6144. (e) Ben, O. A.; Lee, J. W.; Wu, J. S.; Kim, J. S.; Abidi, R.; Thuery, P.; Strub, J. M.; Van Dorsselaer, A.; Vicens, J. J. Org. Chem. 2007, 72, 7634-7640. (f) Lin, W. Y.; Yuan, L.; Long, L. L.; Guo, C. C.; Feng, J. B. Adv. Funct. Mat. 2008, 18, 2366-2372.

(8) (a) Nguyen, B. T.; Anslyn, E. V. Coord. Chem. Rev. 2006, 250, 31183127. (b) Wiskur, S. L.; Lavigne, J. L.; Metzger, A.; Tobey, S. L.; Lynch, V.; Anslyn, E. V. Chem.-Eur. J. 2004, 10, 3792-3804. (c) Kim, S. H.; Choi, J. K.; Kim, S. K.; Sim, W.; Kim, J. S. Tetrahedron Lett. 2006, 47, 3737-3741. (d) Best, M. D.; Tobey, S. L.; Anslyn, E. V. Coord. Chem. Rev. 2003, 240, 3-15. (e) Wiskur, S. L.; AitHaddou, H.; Lavigne, J. J.; Anslyn, E. V. Acc. Chem. Res. 2001, 34, 963-972. (f) Kim, S. K.; Lee, S. H.; Lee, J. Y.; Lee, J. Y.; Bartsch, R. A.; Kim, J. S. J. Am. Chem. Soc. 2004, 126, 16499-116506. 


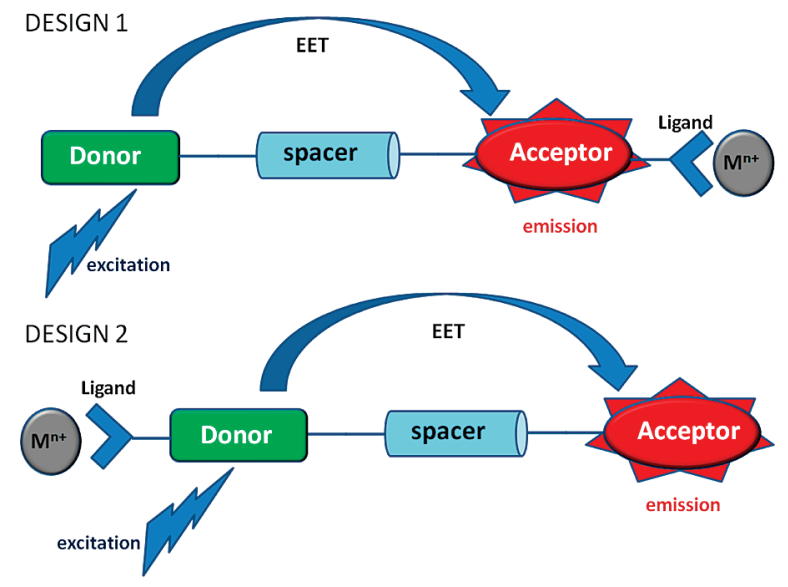

Figure 1. Two different designs for excitation energy transfer coupled ion sensing. Examples of "Design 1" were reported previously. In this work, the consequences of "Design 2" are explored.

concentration differences of the probe compounds; such selfcorrection capacity in fluorescence measurements using these probes is considered to be an instrumental analogue of color vision. ${ }^{9}$

A few years ago, we reported ${ }^{7 \mathrm{a}}$ a novel approach for rational design for large Stokes shift ratiometric chemosensors. Through this methodology, first a dimeric chromophore was synthesized, and with just one chemical conversion, it was transformed into an energy transfer cassette and a chemosensor. Thus, one of the fluorophores was excited at $500 \mathrm{~nm}$, and through very efficient energy transfer (through-bond and through-space) the second chromophore was excited. This second chromophore was in fact a rather standard ICT type of a chemosensor, sensing ions with a blue shift in the emission spectrum. The advantage of this approach was a much larger pseudo-Stokes shift, and tunable excitation and emission wavelengths by the choice of energy donor and acceptor chromophores. This was all possibly due to recently appreciated highly versatile chemistry of boradiazaindacene (a.k.a, BODIPY, borondipyrrin) dyes. A number of research groups worldwide, ${ }^{10}$ in addition to our laboratory, ${ }^{7 \mathrm{a}, \mathrm{b}, 11}$ sparked this recent explosion of interest in Bodipy chemistry and applications.

Through-space energy transfer efficiency is a function of spectral overlap and the distance between the chromophores. In our previous design (Figure 1), we designed and synthesized a ratiometric chemosensor by simply modifiying a dimeric

(9) Tsien, R. Y.; Harootunian, A. T. Cell Calcium 1990, 11, 93-109.

(10) (a) Yogo, T.; Urano, Y.; Ishitsuka, Y.; Maniwa, F.; Nagano, T. J. Am Chem. Soc. 2005, 127, 12162-12163. (b) Loudet, A.; Burgess, K. Chem. Rev. 2007, 107, 4891-4932. (c) Baruah, M.; Qin, W.; Vallee, R. A. L.; Beljonne, D.; Rohand, T.; Dehaen, W.; Boens, N. Org. Lett. 2005, 7, 4377-4380. (d) Qin, W.; Rohand, T.; Baruah, M.; Stefan, A.; Van der Auweraer, M.; Dehaen, W.; Boens, N. Chem. Phys. Lett. 2006, 420, 562-568. (e) Ulrich, G.; Ziessel, R.; Harriman, A. Angew. Chem., Int. Ed. 2008, 47, 1184-1201. (f) Ziessel, R.; Ulrich, G.; Harriman, A. New J. Chem. 2007, 31, 496-501. (g) Descalzo, A. B.; Xu, H. J.; Xue, Z. L.; Hoffmann, K.; Shen, Z.; Weller, M. G.; You, X. Z.; Rurack, K. Org. Lett. 2008, 10, 1581-1584. (h) Rurack, K.; Kollmannsberger, M.; Daub, J.; New, J. Chem. 2001, 25, 289-292.

(11) (a) Deniz, E.; Isbasar, G. C.; Bozdemir, O. A.; Yildirim, L. T.; Siemiarczuk, A.; Akkaya, E. U. Org. Lett. 2008, 10, 3401-3403. (b) Yilmaz, M. D.; Bozdemir, O. A.; Akkaya, E. U. Org. Lett. 2006, 8 , 2871-2873. (c) Atilgan, S.; Ekmekci, Z.; Dogan, A. L.; Guc, D.; Akkaya, E. U. Chem. Commun. 2006, 4398-4400. (d) Ekmekci, Z.; Yilmaz, M. D.; Akkaya, E. U. Org. Lett. 2008, 10, 461-464. (e) Coskun, A.; Deniz, E.; Akkaya, E. U. Org. Lett. 2005, 7, 5187-5189. (f) Cakmak, Y.; Akkaya, E. U. Org. Lett. 2009, 11, 85-88. (g) Atilgan, S.; Ozdemir, T.; Akkaya, E. U. Org. Lett. 2008, 10, 4065-4067.
BODIPY dye via Knoevenagel condensation on the methyl groups on the Bodipy core. This simple modification was enough to transform a simple dimeric dye into an energy transfer cassette carrying a selective ligand (receptor) in full conjugation to one of the Bodipy dyes through a styryl linkage. Total energy transfer to the acceptor (longer wavelength Bodipy) yielded a ratiometric chemosensor with largely improved pseudo-Stokes shift. In that design, the energy transfer was essentially $100 \%$, regardless of the metal ion being bound to the receptor or not. By simply increasing the distance between the donor and acceptor chromophores using rigid ethynylphenyl spacers, we later demonstrated that, it was possible to reduce the energy transfer efficiency. At that reduced level due to larger distance, the efficiency of energy transfer can be modulated by metal ion binding. Thus, metal ion binding was expected to increase the energy transfer efficiency and alter the emission signals as a second, binding event-linked parameter. The result was an improved dynamic range.

In this work, we aimed an exploration of an inverted energy transfer, i.e., the ligand is attached to the energy donor fluorophore, and the energy acceptor fluorophore is essentially a passive emitter. To fulfill these design parameters, we targeted compounds $\mathbf{9 b}-\mathbf{1 0 b}$ (Figure 2).

Synthesis. Synthesis pathways followed were shown in Scheme 1. Briefly, the synthetic work starts with the preparation of 2,6-diethyl-1,3,5,7-tetramethyl-8-(4-iodophenyl)-4,4-difluoro4-bora-s-3a,4a-diazaindacene, compound 1. Double Knoevenagel condensation with 4-butoxybenzaldehyde yields a derivative (2) of the energy acceptor; a longer wavelength absorbing and emitting chromophore. A butyl group proved to be helpful in alleviating solubility problems in rigid and flat aromatic intermediates and target compounds. Sonogashira coupling of 2 with Trimethylsilylacetylene followed by deprotection with $\mathrm{NaOH}$ in $\mathrm{MeOH}$ yielded a very useful intermediate and long wavelength dye module 4 . In order to synthetically access the target molecule with larger separation between the chromophores, an additional phenylethynyl group was placed by reacting compound $\mathbf{4}$ with 4 -(TMS-ethynyl)-iodobenzene under Sonogashira conditions. Then, following deprotection, another coupling with Bodipy $\mathbf{1}$ yielded bichromophoric compound $\mathbf{8}$. Compound $\mathbf{4}$ coupled with $\mathbf{1}$ yielded a similar bichromophoric system 7 with a smaller distance of separation. Compounds 7 and 8 can be reacted with the desired aldehydes to yields sensor compounds 9a, 9b, 10a, and 10b under Knoevenagel condensation conditions. The synthesis of $\mathbf{9 b}$ and $\mathbf{1 0 b}$ requires the use of an aromatic aldehyde carrying an azadithiacrown ligand, which is known to be $\mathrm{Hg}(\mathrm{II})$ selective $^{12}$ in a number of solvent systems.

\section{Results and Discussion}

The absorbance spectra of compounds $\mathbf{7}$ and $\mathbf{8}$ are shown in Figure 3. At equal concentrations $(1.22 \mu \mathrm{M})$ in THF, as expected two major peaks were observed, a shorter wavelength peak at $526 \mathrm{~nm}$ is due to standard Bodipy units with four methyl and two ethyl substituents on the boradiazaindacene core. The larger peak at longer wavelength $(655 \mathrm{~nm})$, on the other hand, originates from distyryl-Bodipy unit. Emission spectra (Figure 4) of the cassettes obtained by excitation at $520 \mathrm{~nm}$ show just one major emission peak which corresponds to the emission

(12) Jimenez, D.; Martinez-Manez, R.; Sancenon, F.; Ros-Lis, J. V.; Soto, J.; Benito, A.; Garcia-Breijo, E. Eur. J. Inorg. Chem. 2005, 23932403. 


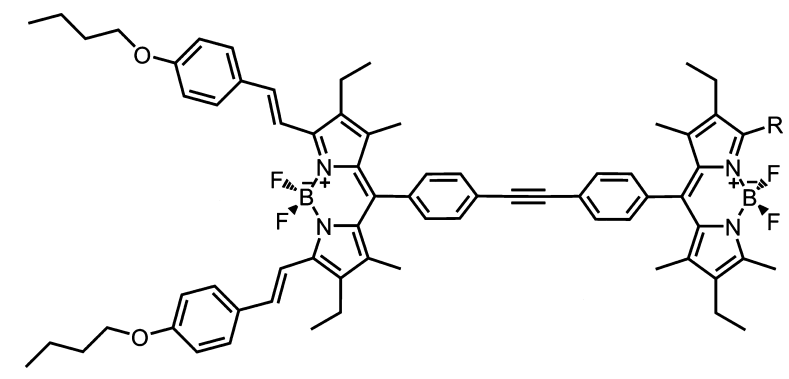

$\mathbf{R}=-\mathrm{CH}_{3}$<smiles>[R]=C=CC=Cc1ccc(N(C)C)cc1</smiles>

$\mathbf{R}=-\mathrm{CH}_{3}$

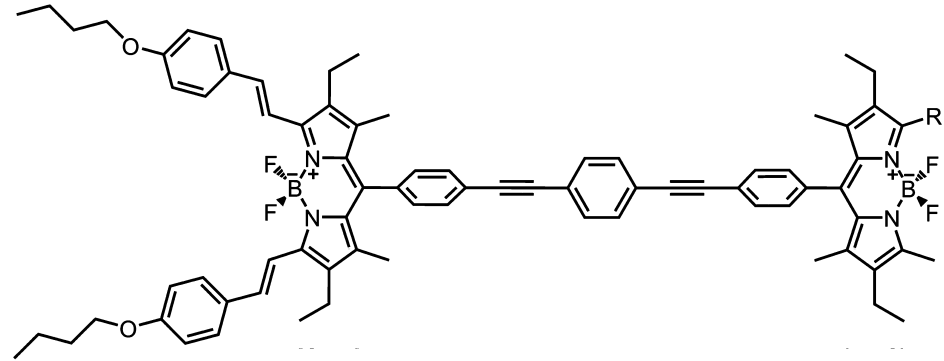<smiles>[R]=CC=Cc1ccc(N2CCSCCOCCOCCSCC2)cc1</smiles>

9b

9 a

10a

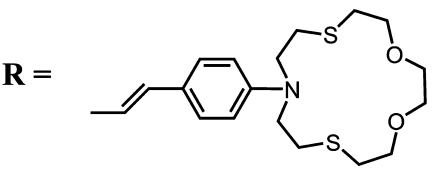

Figure 2. Targeted Bodipy-based energy transfer cassettes and/or ion sensors.

from the long wavelength (red-emitting) distyryl-Bodipy dye. Considering the bright emission characteristics of the parent (unfunctionalized) Bodipy dye, and yet the emission in the relevant region is very weak, it is clear that the energy transfer is highly efficient. There is only very little residual emission around $540 \mathrm{~nm}$ on excitation of the corresponding yellowemitting shorter wavelength chromophore. We should also note that the cassette with larger separation between the chromophores (8) display a larger residual emission in the shorter wavelength region, which is in accordance with Förster energy transfer efficiency being dependent on the distance between the donor and acceptor chromophores.

Following the second round of Knoevenagel condensation at the shorter wavelength chromophore, this chromophore was converted to a monostyryl-Bodipy derivative, with a corresponding red shift of $100 \mathrm{~nm}$ in the absorption peak to $625 \mathrm{~nm}$ (Table 1). Thus, the absorbance spectra of compounds $9 \mathbf{a}, \mathbf{1 0 a}$ (Supporting Information), 9b (Figure 5), and $\mathbf{1 0 b}$ have a common and interesting feature: since the distyryl and monostyryl-

Table 1. Selected Spectroscopic Data for Compounds 7-10

\begin{tabular}{|c|c|c|c|c|c|c|c|}
\hline \multirow[b]{2}{*}{ compound } & \multicolumn{2}{|c|}{$\lambda_{\max }(\mathrm{nm})$} & \multicolumn{2}{|c|}{$\varepsilon_{\max }\left(\mathrm{M}^{-1} \mathrm{~cm}^{-1}\right)$} & \multicolumn{2}{|c|}{ fwhm $\left(\mathrm{cm}^{-1}\right)$} & \multirow[b]{2}{*}{ QY, $\phi^{b}$} \\
\hline & $\lambda_{\max }(\mathrm{d})^{a}$ & $\lambda_{\max }(\mathrm{a})^{a}$ & $\varepsilon(\mathrm{d})^{a}$ & $\varepsilon(\mathrm{a})^{a}$ & fwhm (d) ${ }^{a}$ & fwhm $(a)^{a}$ & \\
\hline 7 & 525 & 657 & 73500 & 95700 & 766 & 1137 & 0.41 \\
\hline 8 & 525 & 657 & 69900 & 84600 & 766 & 986 & 0.46 \\
\hline $9 a$ & \multicolumn{2}{|c|}{652} & \multicolumn{2}{|c|}{63600} & \multicolumn{2}{|c|}{2345} & 0.28 \\
\hline $9 b$ & \multirow{2}{*}{\multicolumn{2}{|c|}{$\begin{array}{l}635 \\
652\end{array}$}} & \multirow{2}{*}{\multicolumn{2}{|c|}{$\begin{array}{l}82400 \\
52400\end{array}$}} & \multicolumn{2}{|c|}{2155} & 0.26 \\
\hline 10a & & & & & 23 & 45 & 0.45 \\
\hline 10b & \multicolumn{2}{|c|}{635} & \multicolumn{2}{|c|}{69500} & \multicolumn{2}{|c|}{2235} & 0.52 \\
\hline $9 a+$ TFA & 580 & 656 & 45700 & 47900 & 1218 & 1083 & 0.76 \\
\hline 9b + $\mathrm{Hg}(\mathrm{II})$ & 581 & 655 & 70400 & 58400 & 1183 & 936 & 0.68 \\
\hline 10a + TFA & 580 & 656 & 38200 & 41800 & 1597 & 1266 & 0.81 \\
\hline 10a $+\operatorname{Hg}(\mathrm{II})$ & 582 & 655 & 57000 & 49000 & 1474 & 1058 & 0.73 \\
\hline
\end{tabular}

\footnotetext{
${ }^{a} \mathrm{~d}$ stands for the energy donor chromophore peak, and a for the energy acceptor chromophore peak. ${ }^{b}$ Quantum yields were determined in reference to Rhodamine $6 \mathrm{G}$ (0.95 in ethanol).
}

Bodipy chromophores had typically broad absorbance peaks, these two peaks corresponding to monostyryl and distyryl derivatives overlap, resulting in a single broader absorption. The observed peak shape is not due to aggregation, as it is unaltered in different solvents and at different concentrations (Supporting Information). Compounds $\mathbf{9 a}$ and $\mathbf{1 0 a}$ are responsive to acid (perchloric acid), and as expected, the energy donor chromophore peaks move to shorter wavelengths on protonation of the diemthylamino function (Supporting Information). When the dyads 9b (Figure 5) and 10b (Supporting Information) were titrated with $\mathrm{Hg}(\mathrm{II})$ ions, the two overlapping absorption peaks tend to resolve into separate peaks as a result of a blue shift in the monostyryl-Bodipy chromophore carrying the azathiacrown ligand as an ICT donor group. This blue shift originates from the decrease in the electron-donating character of the dialkylamino function of the azathiacrown moiety on metal ion binding, in accordance with the general principles of intramolecular charge transfer. ${ }^{13}$ Excitation of the dilute THF solution of $9 \mathbf{b}$ at the wavelength corresponding to $\mathrm{Hg}$ (II)-bound monostryl chromophore $(580 \mathrm{~nm})$ results in a large (more than 5-fold) increase in the emission peak (Figure 6). Benesi-Hildebrand analysis of the data yields a 1:1 binding constant of $7.8 \times 10^{5}$ $\mathrm{M}^{-1}$ (Supporting Information). The interaction between the ligand and $\mathrm{Hg}$ (II) ions is quite selective as evidenced by the plot of emission intensities at $675 \mathrm{~nm}$ (Figure 7). Other ions tested, including softer metal ions such as $\mathrm{Pb}$ (II) and $\mathrm{Cd}(\mathrm{II})$, did not show significant responses at the concentrations used in this study. Excitation spectra (Figure 8) obtained in dilute

(13) Valeur, B. Molecular Fluorescence; Wiley-VCH: Weinheim, Germany, 2002.

(14) Grynkiewicz, G.; Poenie, M.; Tsien, R. Y. J. Biol. Chem. 1985, 260, 3440-3450.

(15) Sudeep, P. K.; Thomas, K. G.; George, M. V.; Barazzouk, S.; Kamat, P. V. Org. Lett. 2002, 2, 29-35.

(16) Hsung, R. P.; Babcock, J. R.; Chidsey, C. E. D.; Sita, L. R. Organometallics 1995, 14, 480. 
Scheme 1. Synthetic Route to the Energy Transfer Cassettes 7, 8 and Chemosensors 9b, 10b

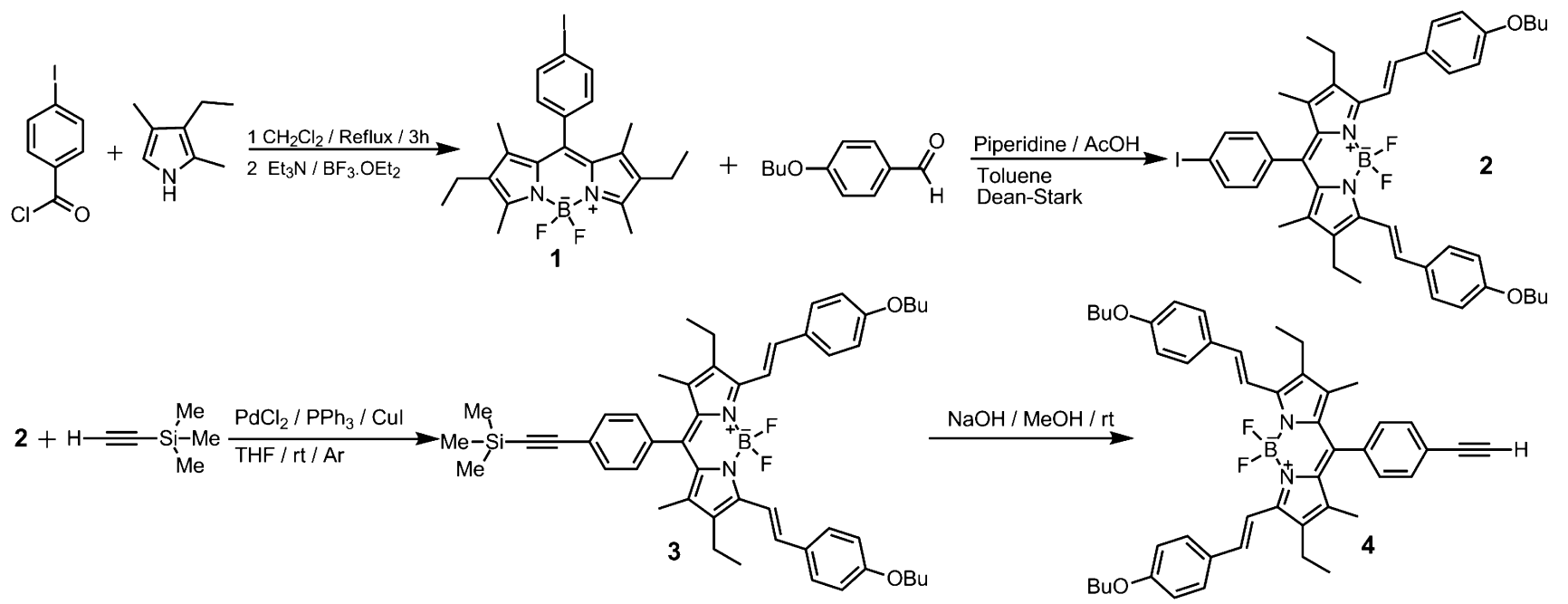

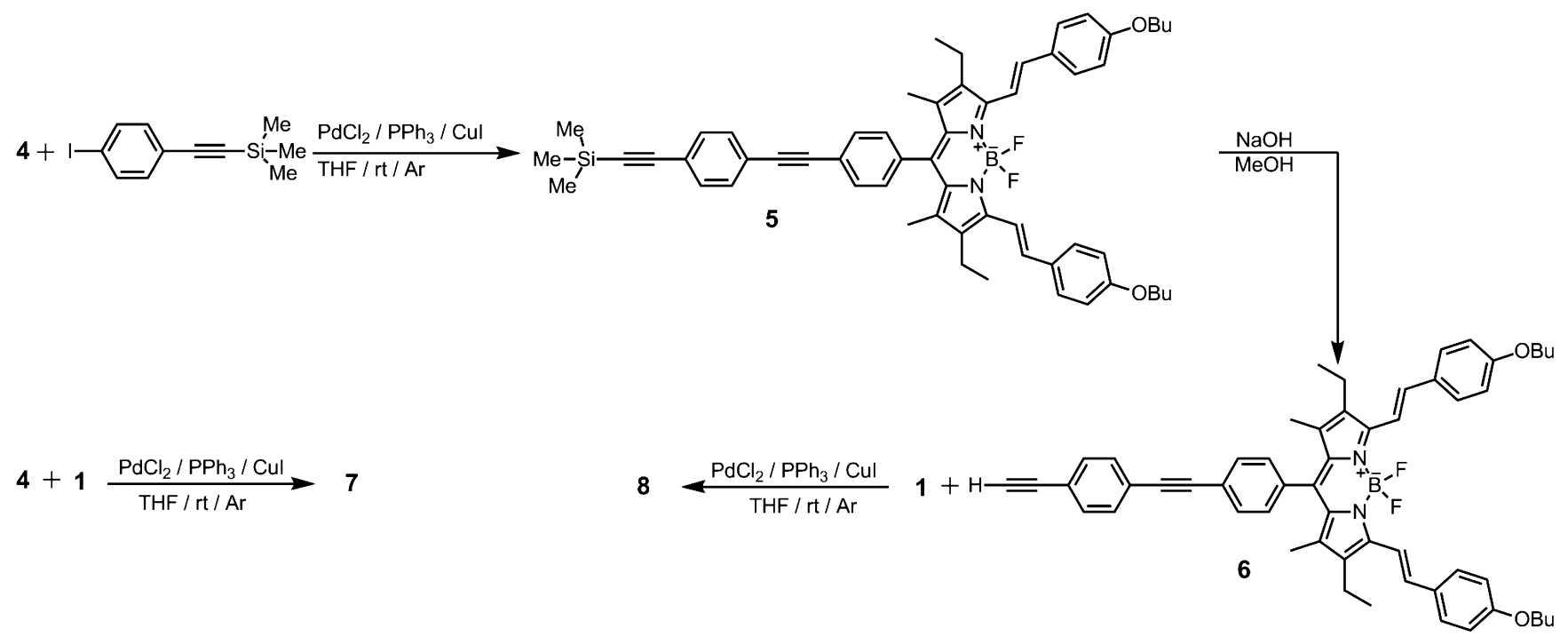

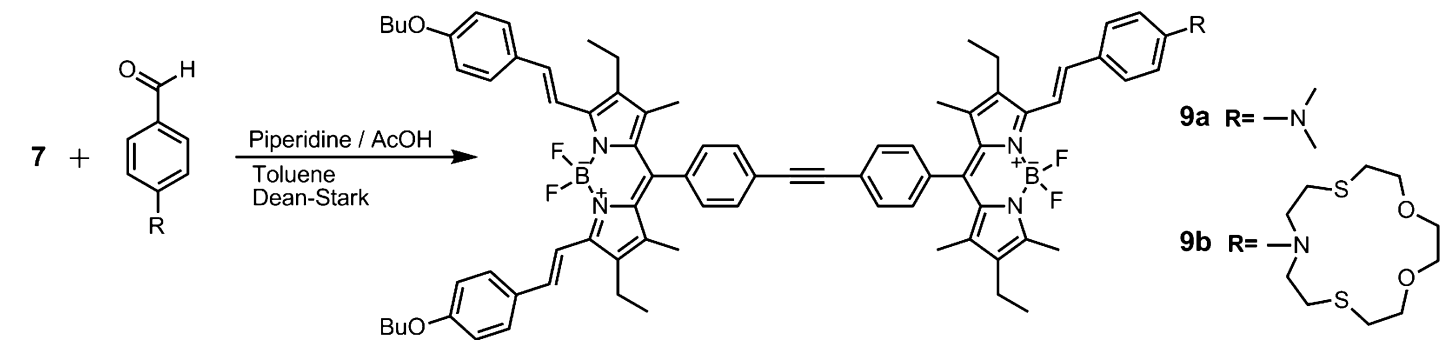

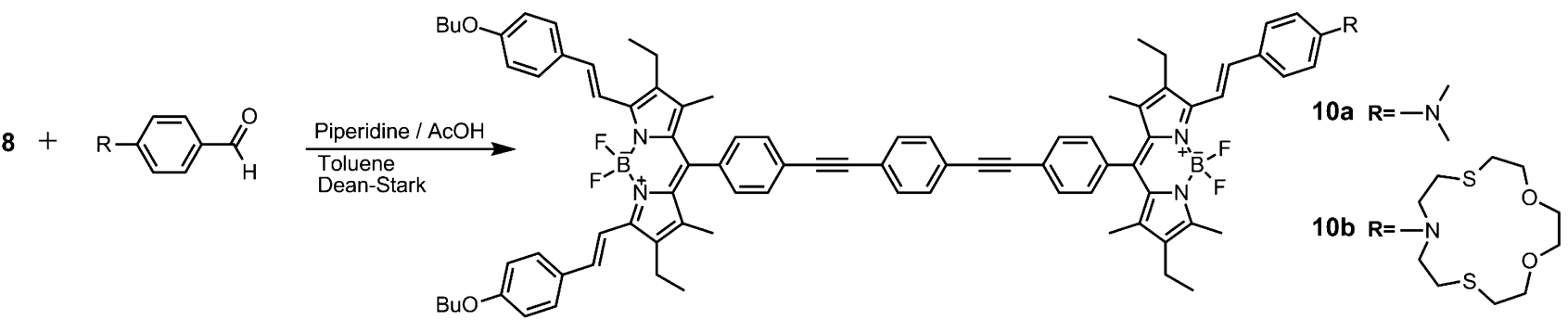

THF solutions of $\mathbf{9 b}$ in the presence of metal ions at $10 \mu \mathrm{M}$ concentration clearly show that only with $\mathrm{Hg}(\mathrm{II})$ ions does the blue shift of the monostyryl absorbance take place, resulting in two separate excitation peaks. Thus, the excitation spectrum very clearly resembles the absorbance spectrum and corroborates other evidence for highly efficient energy transfer.

The titration of the dyad $\mathbf{9 b}$ with $\mathrm{Hg}(\mathrm{II})$, when studied carefully, also reveals the change in energy transfer as a function 


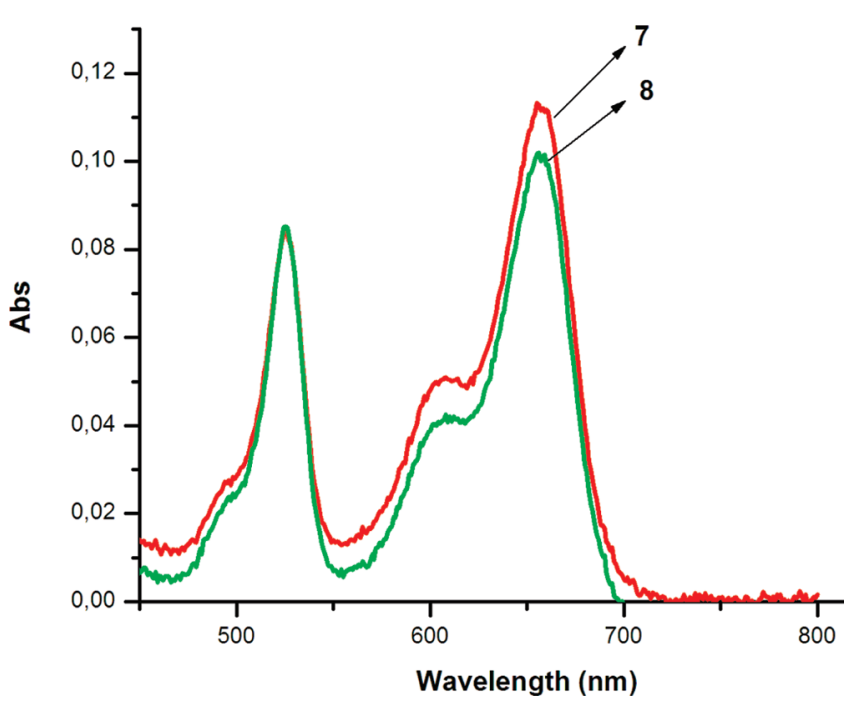

Figure 3. Absorption spectra of compounds 7 and $\mathbf{8 i n}$ THF at $1.17 \times$ $10^{-6} \mathrm{M}$ and $1.11 \times 10^{-6} \mathrm{M}$, respectively.

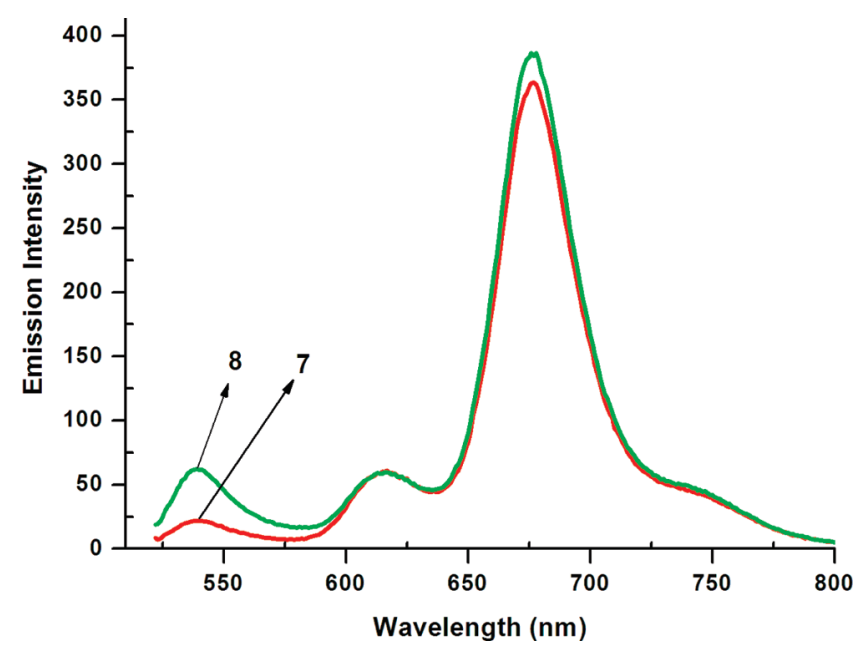

Figure 4. Emission spectra of compounds $\mathbf{7}$ and $\mathbf{8}$ in THF at a concentration of $1.17 \times 10^{-6} \mathrm{M}$ and $1.11 \times 10^{-6} \mathrm{M}$. Excitation was at $520 \mathrm{~nm}$.

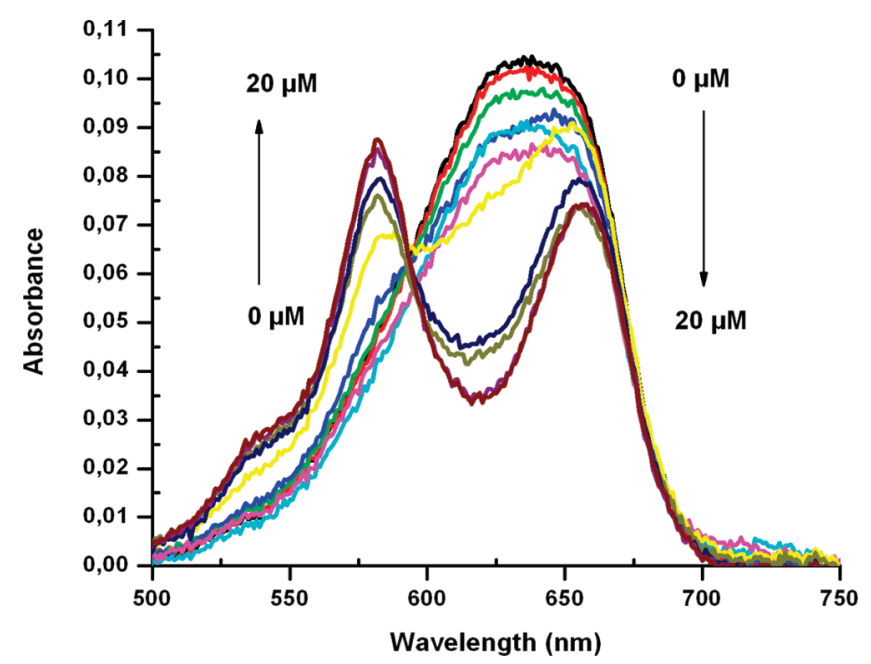

Figure 5. Absorbance spectra of compound $9 \mathbf{b}$ in THF $\left(1.25 \times 10^{-6} \mathrm{M}\right)$ in the presence of increasing $\mathrm{Hg}(\mathrm{II})$ concentrations $(0,1.0,2.0,3.0,4.0$, $5.0,10,15,20 \mu \mathrm{M})$.

of $\mathrm{Hg}(\mathrm{II})$ concentration (hence metal-bound dyad percentage). The emission data in Figure 6 were reanalyzed as follows. When excited at $580 \mathrm{~nm}$, the small peak at around $600 \mathrm{~nm}$ is due to

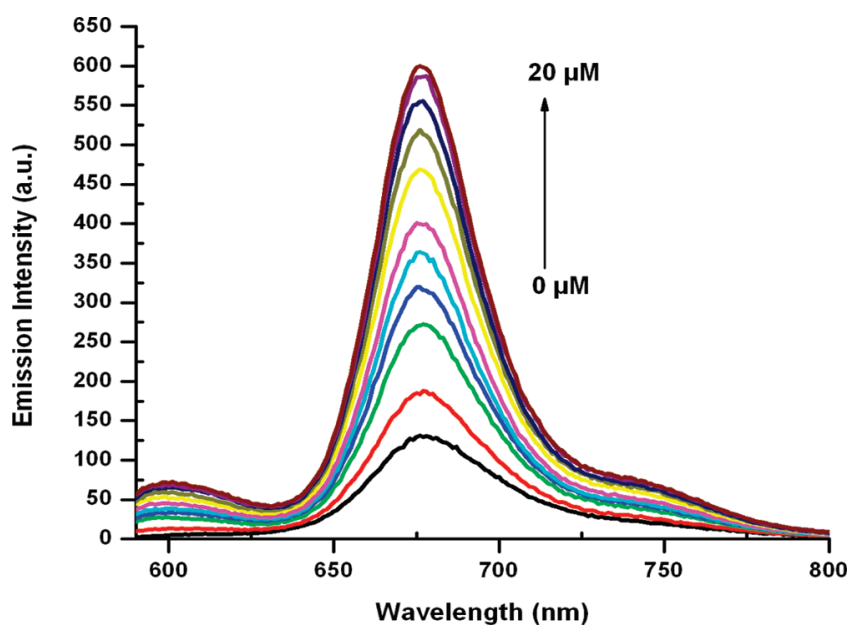

Figure 6. Emission spectra of compound $\mathbf{9 b}$ in THF $\left(1.25 \times 10^{-6} \mathrm{M}\right)$ in the presence of increasing $\mathrm{Hg}(\mathrm{II})$ concentrations $(0,1.0,2.0,3.0,4.0,5.0$, $7.5,10,12.5,15,20 \mu \mathrm{M})$. Excitation was at $580 \mathrm{~nm}$.

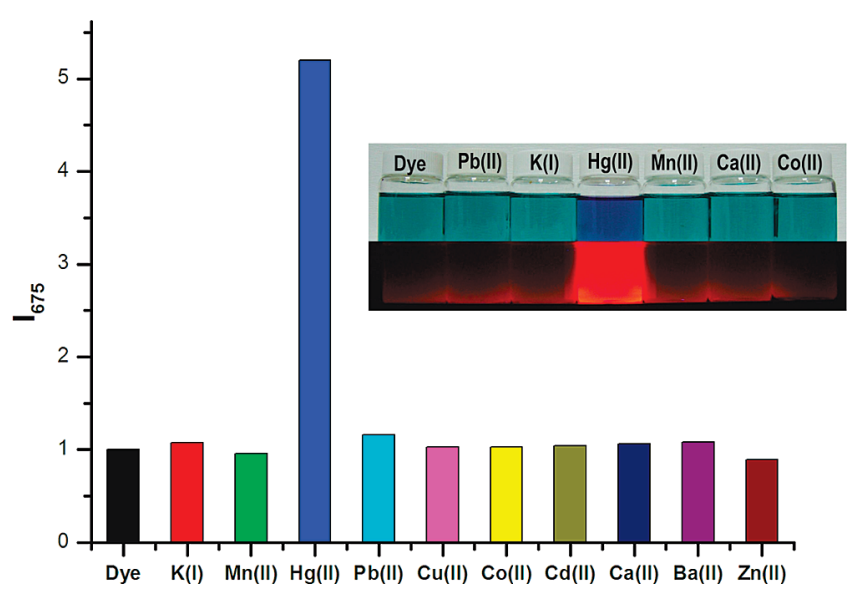

Figure 7. Emission ratios for the compound $\mathbf{9 b}$ (in $\operatorname{THF}\left(1.25 \times 10^{-6} \mathrm{M}\right.$ ) obtained in the presence of different metal cations. The chemosensor was excited at $580 \mathrm{~nm}$, and the ratios of emission data at $675 \mathrm{~nm}$ were calculated. Inset: Digital photograph of vials containing THF solutions of the chemosensor $\mathbf{9 b}$ alone and in the presence of metal ions introduced as anhydrous perchlorate salts. Upper series, under ambient light, lower series under UV illumination at $360 \mathrm{~nm}$.

the fluorescence emission of the shorter wavelength emitting monostyryl dye. The ratio of emission at $675 \mathrm{~nm}$ to the emission at $600 \mathrm{~nm}\left(I_{675} / I_{600}\right)$ is a very useful parameter reflecting the efficiency of energy transfer; as the spectral overlap decreases as a result of the blue shift on $\mathrm{Hg}$ (II) binding, the efficiency of energy transfer decreases. The emission intensity at $675 \mathrm{~nm}$ increases, but this is only due to increasing absorbance at the excitation wavelength. The intensity data ratios at $675 / 600 \mathrm{~nm}$, as obtained from the spectra shown in Figure 6 when plotted as a function of $\mathrm{Hg}$ (II) concentrations, display very clearly that as the metal ion concentration increases, energy transfer efficiency decreases (Figure 9). On the other hand, the chemosensors $9 \mathrm{~b}$ and $\mathbf{1 0 b}$ should be excitation ratiometric by virtue of their design. The excitation spectra shown in Figure 8 is sufficient to establish this fact. Excitation data at two selected wavelengths, 580 and $620 \mathrm{~nm}$, yields the optimal results: The excitation ratio at zero metal ion concentration $\left(I_{580} / I_{620}\right)$ gives a value of 1.93 , whereas the same ratio at $10 \mu \mathrm{M} \mathrm{Hg}$ (II) results 


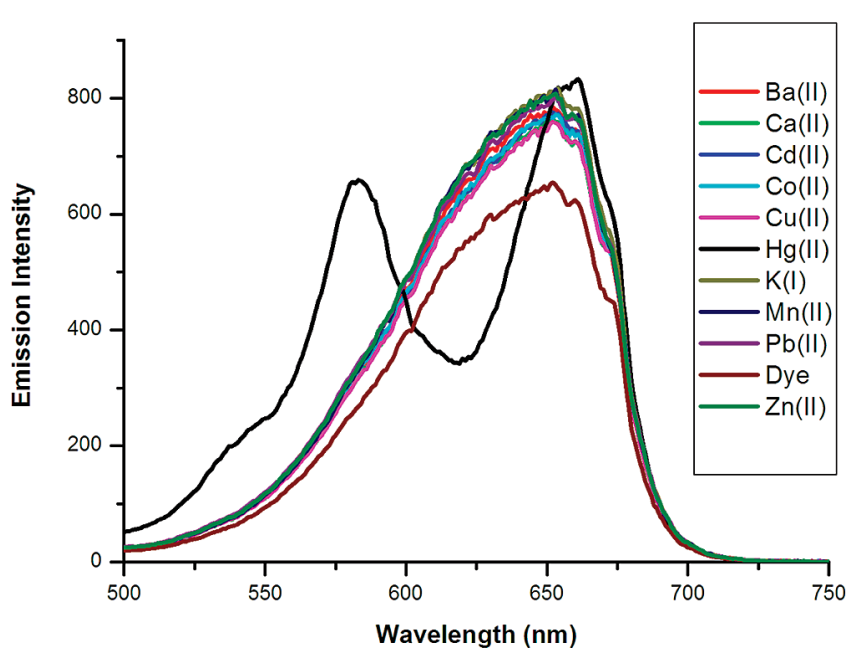

Figure 8. Excitation spectrum of compound $\mathbf{9 b}$ in the presence of various cations $(50 \mu \mathrm{M})$ (followed at $675 \mathrm{~nm})$.

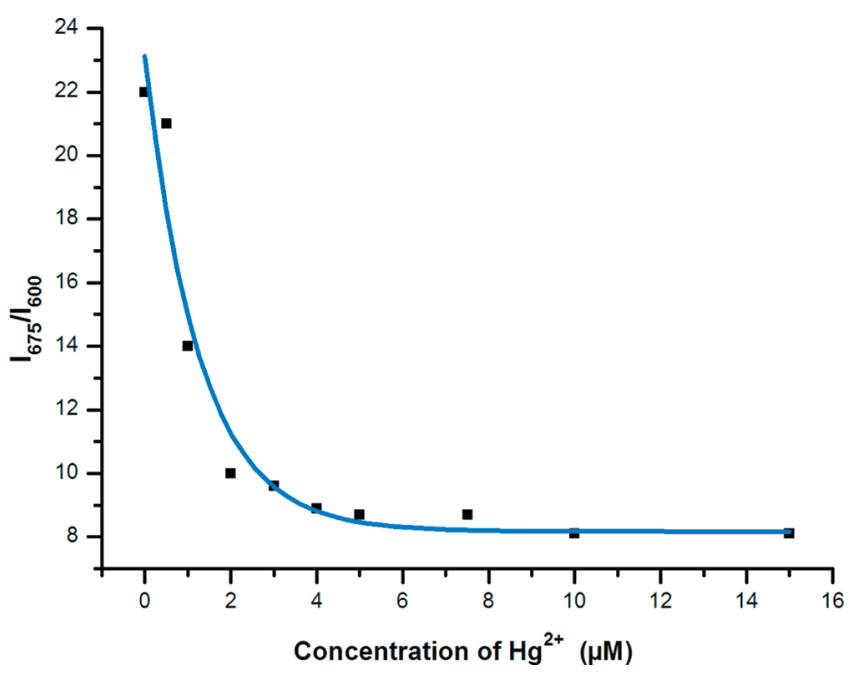

Figure 9. $I_{675} / I_{600}$ ratio as an indicator of energy transfer efficiency. Data were collected from the spectra shown in Figure 6.

in a value of 0.48 . A 2 -fold change in the excitation ratios is considered highly satisfactory for ratiometric chemosensors. ${ }^{14}$

\section{Conclusion}

With this work we were able to generalize our earlier designs for excitation energy transfer coupled ion sensing using a different design, where primarily the spectral characteristics of the energy donor chromophore were modulated. The result is a lesser energy transfer as the metal ion binds the ligand. The spectral position of the major emission peak at longer wavelengths is not changed, in effect resulting in dual-excitation ratiometric chemosensors. Modular design and remarkable tunability of Bodipy spectral characteristics by simple derivatizations are the two main reasons why this approach in chemosensor development looks highly promising.

\section{Experimental Section}

Distyryl-Bodipy Compound 2. Compound 1 (1.0 mmol, 506 $\mathrm{mg})$ and 4-butoxybenzaldehyde $(2.2 \mathrm{mmol}, 392 \mathrm{mg}$; synthesized according to literature procedure ${ }^{15}$ ) were refluxed in a mixture of benzene $(40.0 \mathrm{~mL})$, glacial acetic acid $(440 \mu \mathrm{L})$, and piperidine $(530 \mu \mathrm{L})$. Water formed during the reaction was removed azeotropically by heating overnight in a Dean-Stark apparatus. Crude product concentrated under vacuum and then purified by silica gel column chromatography $\left(\mathrm{CHCl}_{3}\right.$ as eluent) afforded a green colored fraction that was collected (700 mg, 84\%). ${ }^{1} \mathrm{H} \mathrm{NMR}(400 \mathrm{MHz}$, $\left.\mathrm{CDCl}_{3}\right) \delta 7.85(\mathrm{~d}, 2 \mathrm{H}, J=7.9 \mathrm{~Hz}), 7.66(\mathrm{~d}, 2 \mathrm{H}, J=16.7 \mathrm{~Hz})$, $7.55(\mathrm{~d}, 4 \mathrm{H}, J=8.6 \mathrm{~Hz}), 7.21(\mathrm{~d}, 2 \mathrm{H}, J=16.8 \mathrm{~Hz}), 7.08(\mathrm{~d}, 2 \mathrm{H}$, $J=8.1 \mathrm{~Hz}), 6.92(\mathrm{~d}, 4 \mathrm{H}, J=8.6 \mathrm{~Hz}), 4.00(\mathrm{t}, 4 \mathrm{H}, J=6.5 \mathrm{~Hz})$, $2.60(\mathrm{p}, 4 \mathrm{H}, J=8.5 \mathrm{~Hz}), 1.83-1.77(\mathrm{~m}, 4 \mathrm{H}), 1.40(\mathrm{~s}, 6 \mathrm{H}), 1.15(\mathrm{t}$, $6 \mathrm{H}, J=7.5 \mathrm{~Hz}), 1.00(\mathrm{t}, 6 \mathrm{H}, J=7.4 \mathrm{~Hz}) \cdot{ }^{13} \mathrm{C} \mathrm{NMR}(100 \mathrm{MHz}$, $\left.\mathrm{CDCl}_{3}\right) \delta 159.9,151.0,150.8,138.3,135.8,133.8,132.4,130.8$, $130.1,128.8,117.9,114.8,94.5,67.9,31.3,19.2,18.4,14.0,13.8$, $11.9,11.8$

TMS-Ethynyl Derivative 3. Compound $3(0.3 \mathrm{mmol}, 248 \mathrm{mg})$, $\mathrm{PdCl}_{2}$ (0.06 mmol, $\left.10.6 \mathrm{mg}\right), \mathrm{CuI}(0.12 \mathrm{mmol}, 23 \mathrm{mg})$, and $\mathrm{PPh}_{3}$ $(0.24 \mathrm{mmol}, 63 \mathrm{mg})$ were added to the round bottomed flask which was previously flushed with argon. As a solvent, $\mathrm{Et}_{3} \mathrm{~N}(5.0 \mathrm{~mL})$ and anhydrous THF $(50.0 \mathrm{~mL})$ were added. The solution was degassed with argon for $15 \mathrm{~min}$. Trimethylsilylacetylene $(0.70$ mmol, $0.1 \mathrm{~mL}$ ) was then added. The reaction mixture was stirred overnight at room temperature. After completion of the reaction, solvent was removed in vacuo. The crude product purified by silica gel column chromatography (eluent: $\mathrm{CHCl}_{3}$ ). Green solid (210 mg, 87\%). ${ }^{1} \mathrm{H}$ NMR (400 MHz, $\left.\mathrm{CDCl}_{3}\right) \delta 7.50(\mathrm{~d}, 2 \mathrm{H}, J=15.8 \mathrm{~Hz})$, $7.42(\mathrm{~d}, 2 \mathrm{H}, J=8.1 \mathrm{~Hz}), 7.35(\mathrm{~d}, 4 \mathrm{H} J=7.9 \mathrm{~Hz}), 7.10(\mathrm{~d}, 2 \mathrm{H}, J$ $=8.2 \mathrm{~Hz}), 7.02(\mathrm{~d}, 2 \mathrm{H}, J=16.1 \mathrm{~Hz}), 6.70(\mathrm{~d}, 4 \mathrm{H}, J=8.4 \mathrm{~Hz})$, $3.80(\mathrm{t}, 4 \mathrm{H}, J=6.4 \mathrm{~Hz}), 2.46-2.39(\mathrm{~m}, 4 \mathrm{H}), 1.66-1.58(\mathrm{~m}, 4 \mathrm{H})$, $1.35-1.26(\mathrm{~m}, 6 \mathrm{H}), 1.15(\mathrm{~s}, 6 \mathrm{H}), 1.00(\mathrm{t}, 6 \mathrm{H}, J=7.5 \mathrm{~Hz}), 0.80(\mathrm{t}$, $6 \mathrm{H}, J=7.3 \mathrm{~Hz}), 0.12(\mathrm{~s}, 9 \mathrm{H}) .{ }^{13} \mathrm{C} \mathrm{NMR}\left(100 \mathrm{MHz}, \mathrm{CDCl}_{3}\right) \delta$ 159.9, 150.8, 138.5, 136.8, 135.7, 134.4, 132.7, 130.2, 129.6, 128.3, $127.7,123.8,118.0,114.9,104.5,95.7,67.9,31.4,19.3,18.5,14.1$, $13.9,11.8,0.0$

Deprotection of Compound 3. $\mathrm{NaOH}(2.0 \mathrm{mmol}, 80.0 \mathrm{mg})$ in $5.0 \mathrm{~mL}$ of $\mathrm{MeOH}$ was added to a solution of $\mathbf{3}(1.0 \mathrm{mmol}, 800$ $\mathrm{mg})$ in $\mathrm{MeOH} / \mathrm{CH}_{2} \mathrm{Cl}_{2}(10 \mathrm{~mL} / 30 \mathrm{~mL})$. The solution was stirred at rt for $1 \mathrm{~h}$, until the complete consumption of the starting material was observed by TLC $\left(\mathrm{CHCl}_{3} / \mathrm{Hex} 1: 1\right)$. Water $(30.0 \mathrm{~mL})$ was added, and the solution was extracted with $\mathrm{CH}_{2} \mathrm{Cl}_{2}(3 \times 30 \mathrm{~mL})$. The organic layer was concentrated under reduced pressure and then subjected to column chromatography on silica (eluent: $\mathrm{CHCl}_{3}$ ), yielding the deprotected compound $4(680 \mathrm{mg}, 93 \%)$. ${ }^{1} \mathrm{H}$ NMR $\left(400 \mathrm{MHz}, \mathrm{CDCl}_{3}\right) \delta 7.60(\mathrm{~d}, 2 \mathrm{H}, J=15.7 \mathrm{~Hz}), 7.50(\mathrm{~d}, 2 \mathrm{H}, J=$ $8.1 \mathrm{~Hz}), 7.40$ (d, 4H, $J=7.9 \mathrm{~Hz}), 7.24(\mathrm{~d}, 2 \mathrm{H}, J=8.1 \mathrm{~Hz}), 7.15$ $(\mathrm{d}, 2 \mathrm{H}, J=16.7 \mathrm{~Hz}), 6.80(\mathrm{~d}, 4 \mathrm{H}, J=8.3 \mathrm{~Hz}), 3.90(\mathrm{t}, 4 \mathrm{H}, J=$ $6.4 \mathrm{~Hz}), 3.10(\mathrm{~s}, 1 \mathrm{H}), 2.58-2.48(\mathrm{~m}, 4 \mathrm{H}), 1.77-1.70(\mathrm{~m}, 4 \mathrm{H})$, $1.45-1.38(\mathrm{~m}, 6 \mathrm{H}), 1.30(\mathrm{~s}, 6 \mathrm{H}), 1.10(\mathrm{t}, 6 \mathrm{H}, J=7.3 \mathrm{~Hz}), 0.90(\mathrm{t}$, $6 \mathrm{H}, J=7.2 \mathrm{~Hz}$ ). Used without further purification.

Phenylethynyl Spacer Extension (compound 5). (2-(4-Iodophenyl)ethynyl)trimethylsilane $(0.4 \mathrm{mmol}, 120 \mathrm{mg}$; synthesized according to literature procedure $\left.{ }^{16}\right)$, compound 4 (0.33 mmol, 240 $\mathrm{mg}), \mathrm{PdCl}_{2}(0.06 \mathrm{mmol}, 10.6 \mathrm{mg}), \mathrm{CuI}(0.12 \mathrm{mmol}, 23 \mathrm{mg})$, and $\mathrm{PPh}_{3}(0.24 \mathrm{mmol}, 63.0 \mathrm{mg})$ were added to the round bottomed flask which was previously flushed with argon. As a solvent, $\mathrm{Et}_{3} \mathrm{~N}$ (5.0 $\mathrm{mL})$ and anhydrous THF $(30.0 \mathrm{~mL})$ were added. The reaction mixture was stirred overnight at room temperature. After completion of the reaction, solvent was removed in vacuo. The crude product purified by silica gel column chromatography (eluent: $\mathrm{CHCl}_{3}$ ). Green solid (130 mg, 44\%). ${ }^{1} \mathrm{H}$ NMR (400 $\left.\mathrm{MHz}, \mathrm{CDCl}_{3}\right) \delta$ $7.62-7.55(\mathrm{~m}, 4 \mathrm{H}), 7.48(\mathrm{~d}, 4 \mathrm{H}, J=8.6 \mathrm{~Hz}), 7.46-7.37(\mathrm{~m}, 2 \mathrm{H})$ $7.34-7.10(\mathrm{~m}, 2 \mathrm{H}), 6.85(\mathrm{~d}, 4 \mathrm{H}, J=8.4 \mathrm{~Hz}), 3.90(\mathrm{t}, 4 \mathrm{H}, J=6.5$ $\mathrm{Hz}), 2.50(\mathrm{~m}, 4 \mathrm{H}), 1.70(\mathrm{~m}, 4 \mathrm{H}), 1.40(\mathrm{~m}, 6 \mathrm{H}), 1.30(\mathrm{~s}, 6 \mathrm{H}), 1.10$ $(\mathrm{t}, 6 \mathrm{H}, J=7.4 \mathrm{~Hz}), 0.90(\mathrm{t}, 6 \mathrm{H}, J=7.4 \mathrm{~Hz}), 0.20(\mathrm{~s}, 9 \mathrm{H}) .{ }^{13} \mathrm{C}$ NMR $\left(100 \mathrm{MHz}, \mathrm{CDCl}_{3}\right) \delta 160.0,150.8,138.5,136.8,135.8,133.9$, 132.8, 132.3, 131.7, 131.5, 130.2, 129.2, 128.9, 123.8, 123.4, 123.0, $118.1,114.9,104.6,96.6,90.7,90.4,67.9,31.4,29.7,19.3,18.4$, 14.1, 13.9, 11.8, 0.0.

Deprotection of Compound 5. Deprotection of compound 5 (0.5 $\mathrm{mmol}, 450 \mathrm{mg}$ ) was carried out following the same procedure used for the deprotection of compound $\mathbf{3}$. The crude product $\mathbf{6}$ was used in the next step without further purification (330 mg, 82\%). 
Dyad 7. Compound 1 (0.2 mmol, $110 \mathrm{mg})$, compound 4 (0.2 $\mathrm{mmol}, 150.0 \mathrm{mg}), \mathrm{PdCl}_{2}(0.06 \mathrm{mmol}, 11.0 \mathrm{mg}), \mathrm{CuI}(0.12 \mathrm{mmol}$, $23.0 \mathrm{mg})$, and $\mathrm{PPh}_{3}(0.24 \mathrm{mmol}, 63.0 \mathrm{mg})$ were added to the round bottomed flask which was previously flushed with argon. As a solvent, $\mathrm{Et}_{3} \mathrm{~N}(5.0 \mathrm{~mL})$ and anhydrous THF $(50.0 \mathrm{~mL})$ were added. The mixture was heated at $60{ }^{\circ} \mathrm{C}$ under argon for $24 \mathrm{~h}$, until the complete consumption of starting material was observed. The solution was evaporated to dryness, and the product was purified by column chromatography on silica (eluent: $\mathrm{CHCl}_{3}$ ), yielding the desired compound 7 (90.0 mg, 41\%). ${ }^{1} \mathrm{H}$ NMR (400 MHz, $\mathrm{CDCl}_{3}$ ) $\delta 7.67-7.60(\mathrm{~m}, 4 \mathrm{H}), 7.58(\mathrm{~d}, 2 \mathrm{H}, J=15.9 \mathrm{~Hz}), 7.50(\mathrm{~d}, 4 \mathrm{H}, J=$ $8.1 \mathrm{~Hz}), 7.29-7.22(\mathrm{~m}, 4 \mathrm{H}), 7.15(\mathrm{~d}, 2 \mathrm{H}, J=16.2 \mathrm{~Hz}), 6.85(\mathrm{~d}$, $4 \mathrm{H}, J=8.6 \mathrm{~Hz}), 3.90(\mathrm{t}, 4 \mathrm{H}, J=6.5 \mathrm{~Hz}), 2.50(\mathrm{~m}, 4 \mathrm{H}), 2.45(\mathrm{~s}$, $6 \mathrm{H}), 2.20(\mathrm{~m}, 4 \mathrm{H}), 1.70(\mathrm{~m}, 4 \mathrm{H}), 1.40(\mathrm{~m}, 4 \mathrm{H}), 1.30(\mathrm{~s}, 6 \mathrm{H}), 1.25$ $(\mathrm{s}, 6 \mathrm{H}), 1.10(\mathrm{t}, 6 \mathrm{H}, J=7.5 \mathrm{~Hz}), 0.90(\mathrm{t}, 12 \mathrm{H}, J=6.7 \mathrm{~Hz}) .{ }^{13} \mathrm{C}$ NMR $\left(100 \mathrm{MHz}, \mathrm{CDCl}_{3}\right) \delta 159.9,154.1,150.8,139.2,138.4,138.2$, 136.7, 136.2, 135.8, 133.8, 133.0, 132.7, 132.3, 130.6, 130.3, 130.1, 129.2, 128.8, 123.5, 117.9, 114.9, 90.1, 67.9, 31.3, 19.3, 18.4, 17.3, $17.1,14.6,14.08,13.9,12.6,11.9,11.7,9.4$. MALDI-TOF-MS calcd for $[\mathrm{M}]^{+}$1102.6, found 1102.9 .

Dyad 8. Sonagashira coupling of compounds $\mathbf{1}$ and $\mathbf{6}$ were done following the same procedure used for the synthesis of dyad 7 . Purification by column chromatography on silica (eluent: $\mathrm{CHCl}_{3}$ ) yielded 8 (140 mg, 46\%). ${ }^{1} \mathrm{H} \mathrm{NMR}\left(400 \mathrm{MHz}, \mathrm{CDCl}_{3}\right) \delta 7.66-7.55$ $(\mathrm{m}, 6 \mathrm{H}), 7.50(\mathrm{~s}, 4 \mathrm{H}), 7.45(\mathrm{~d}, 4 \mathrm{H}, J=7.9 \mathrm{~Hz}), 7.36-7.22(\mathrm{~m}$, $4 \mathrm{H}), 7.15(\mathrm{~d}, 2 \mathrm{H}, J=18.3 \mathrm{~Hz}), 6.85(\mathrm{~d}, 4 \mathrm{H}, J=8.6 \mathrm{~Hz}) 3.90(\mathrm{t}$, $4 \mathrm{H}, J=6.4 \mathrm{~Hz}), 2.59-2.52(\mathrm{~m}, 4 \mathrm{H}), 2.47(\mathrm{~s}, 6 \mathrm{H}), 2.28-2.19(\mathrm{~m}$, $4 \mathrm{H}), 1.77-1.68(\mathrm{~m}, 4 \mathrm{H}), 1,51-1.44(\mathrm{~m}, 4 \mathrm{H}), 1.30(\mathrm{~s}, 6 \mathrm{H}), 1.26$ $(\mathrm{s}, 6 \mathrm{H}), 1.10(\mathrm{t}, 6 \mathrm{H}, J=7.2 \mathrm{~Hz}), 0.90(\mathrm{t}, 12 \mathrm{H}, J=7.3 \mathrm{~Hz}) .{ }^{13} \mathrm{C}$ NMR $\left(100 \mathrm{MHz}, \mathrm{CDCl}_{3}\right) \delta 158.9,153.1,137.4,137.2,135.1,134.7$, 132.8, 140.0, 131.7, 131.2, 130.7, 129.6, 129.1, 128.1, 127.7, 127.6, $122.6,122.1,116.9,113.8,89.9,66.8,30.3,18.2,17.4,16.1,13.6$, $13.0,12.8,11.5,10.9,10.7$. MALDI-TOF-MS calcd for $[\mathrm{M}]^{+}$ 1202.7, found 1202.9 .

Compound 9a. Compound $7(0.045 \mathrm{mmol}, 50 \mathrm{mg})$ and $p$ (dimethylamino)benzaldehyde $(0.05 \mathrm{mmol}, 7.5 \mathrm{mg})$ were refluxed in a mixture of benzene $(40.0 \mathrm{~mL})$, glacial acetic acid $(0.5 \mathrm{~mL})$, and piperidine $(0.5 \mathrm{~mL})$. Any water formed during the reaction, was removed azeotropically by heating overnight in a Dean-Stark apparatus. The solvent was removed in vacuo, and then crude product was purified by preparative thin layer chromatography (solvent: $\mathrm{CHCl}_{3}$ ). Dark blue colored fraction was collected (15.0 mg, 27\%). ${ }^{1} \mathrm{H}$ NMR (400 MHz, $\left.\mathrm{CDCl}_{3}\right) \delta 7.72-7.68(\mathrm{~m}, 4 \mathrm{H}), 7.63$ $(\mathrm{d}, 1 \mathrm{H}, J=16.7 \mathrm{~Hz}), 7.53(\mathrm{~d}, 4 \mathrm{H}, J=8.4 \mathrm{~Hz}), 7.48(\mathrm{~d}, 2 \mathrm{H}, J=$ $15.9 \mathrm{~Hz}), 7.37-7.31(\mathrm{~m}, 4 \mathrm{H}), 7.20(\mathrm{~d}, 1 \mathrm{H}, J=16.4 \mathrm{~Hz}), 6.90(\mathrm{~d}$, $4 \mathrm{H}, J=8.6 \mathrm{~Hz}), 6.70(\mathrm{~d}, 2 \mathrm{H}, J=15.9 \mathrm{~Hz}), 4.00(\mathrm{t}, 4 \mathrm{H}, J=7.6$ $\mathrm{Hz}), 3.00$ (s, 6H), 2.64-2.55 (m, 4H), 2.52 (s, 3H), 1.81-1.73 (m, $4 \mathrm{H}), 1.54-1.46(\mathrm{~m}, 4 \mathrm{H}), 1.40(\mathrm{~s}, 6 \mathrm{H}), 1.35(\mathrm{~s}, 6 \mathrm{H}), 1.18-1.10$ (m, 9H), 0.99-0.92 (m, 9H). $\left.{ }^{13} \mathrm{C} \mathrm{NMR} \mathrm{(100} \mathrm{MHz,} \mathrm{CDCl}_{3}\right) \delta 159.9$, $150.8,138.4$, 137.2, 136.6, 135.7, 133.8, 133.4, 132.7, 132.2, 131.2, $130.1,129.2,129.0,128.8,128.8,123.6,123.4,117.9,114.8,112.4$, 108.3, 90.2, 90.0, 67.9, 40.4, 31.3, 29.7, 19.2, 18.4, 17.1, 14.6, 14.0, $13.8,12.6,11.8,11.7,11.6$. MALDI-TOF-MS calcd for $[\mathrm{M}]^{+}$ 1233.6, found 1233.9 .

Compound 10a. Compound $8(0.042 \mathrm{mmol}, 50 \mathrm{mg})$ and p-(dimethylamino)benzaldehyde $(0.05 \mathrm{mmol}, 7.5 \mathrm{mg})$ were refluxed in a mixture of benzene $(40.0 \mathrm{~mL})$, glacial acetic acid $(0.5 \mathrm{~mL})$, and piperidine $(0.5 \mathrm{~mL})$. The procedure followed was essentially identical to that for compound 9a. Dark blue colored fraction was collected (12 mg, 20\%). ${ }^{1} \mathrm{H}$ NMR (400 MHz, $\left.\mathrm{CDCl}_{3}\right) \delta 7.67-7.61$ $(\mathrm{m}, 6 \mathrm{H}), 7.60(\mathrm{~d}, 1 \mathrm{H}, J=16.7 \mathrm{~Hz}), 7.58-7.48(\mathrm{~m}, 8 \mathrm{H}), 7.32-7.24$ (m, 4H), 7.18-7.07 (m, 3H), $6.85(\mathrm{~d}, 4 \mathrm{H}, J=8.6 \mathrm{~Hz}), 3.90(\mathrm{t}$, $4 \mathrm{H}, J=7.6 \mathrm{~Hz}), 3.00(\mathrm{~s}, 6 \mathrm{H}), 2.68-2.56(\mathrm{~m}, 7 \mathrm{H}), 1.86-1.77(\mathrm{~m}$, $4 \mathrm{H}), 1.54-1.48(\mathrm{~m}, 4 \mathrm{H}), 1.40(\mathrm{~s}, 6 \mathrm{H}), 1.35(\mathrm{~s}, 6 \mathrm{H}), 1.14-1.07$ $(\mathrm{m}, 9 \mathrm{H}), 0.98-0.89(\mathrm{~m}, 9 \mathrm{H})$. MALDI-TOF-MS calcd for $[\mathrm{M}]^{+}$ 1333.7, found 1333.9.

Compound 9b. Compound 7 (0.045 mmol, $50 \mathrm{mg})$ and 4-(1aza-7,10-dioxa-4,13-dithiacyclopentadecyl)benzaldehyde ( $0.05 \mathrm{mmol}$, $18 \mathrm{mg}$; synthesized according to literature procedure ${ }^{17}$ ) were refluxed in a mixture of benzene $(40.0 \mathrm{~mL})$, glacial acetic acid $(0.5$ $\mathrm{mL})$, and piperidine $(0.5 \mathrm{~mL})$. Any water formed during the reaction was removed azeotropically by heating overnight in a Dean-Stark apparatus. The solvent was removed in vacuo, and then the crude product was purified by preparative thin layer chromatography (solvent: $\mathrm{CHCl}_{3}$ ). The green colored fraction was collected $(20.0$ $\mathrm{mg}, 31 \%) .{ }^{1} \mathrm{H}$ NMR $\left(400 \mathrm{MHz}, \mathrm{CDCl}_{3}\right) \delta 7.68-7.61(\mathrm{~m}, 4 \mathrm{H}), 7.58$ $(\mathrm{d}, 1 \mathrm{H}, J=15.8 \mathrm{~Hz}), 7.50(\mathrm{~d}, 4 \mathrm{H}, J=8.4 \mathrm{~Hz}), 7.42(\mathrm{~d}, 2 \mathrm{H}, J=$ $16.6 \mathrm{~Hz}), 7.31-7.24(\mathrm{~m}, 4 \mathrm{H}), 7.12(\mathrm{~d}, 1 \mathrm{H}, J=15.4 \mathrm{~Hz}), 6.85(\mathrm{~d}$, $4 \mathrm{H}, J=8.4 \mathrm{~Hz}), 6.59(\mathrm{~d}, 2 \mathrm{H}, J=15.9 \mathrm{~Hz}), 3.90(\mathrm{t}, 4 \mathrm{H}, J=6.9$ $\mathrm{Hz}), 3.70-3.62(\mathrm{~m}, 4 \mathrm{H}), 3.59-3.51(\mathrm{~m}, 8 \mathrm{H}), 2.90-2.81(\mathrm{~m}, 4 \mathrm{H})$, $2.71-2.65(\mathrm{~m}, 4 \mathrm{H}), 2.53-2.49(\mathrm{~m}, 4 \mathrm{H}), 2.47(\mathrm{~s}, 3 \mathrm{H}), 2.30-2.20$ $(\mathrm{m}, 2 \mathrm{H}), 1.78-1.70(\mathrm{~m}, 4 \mathrm{H}), 1.49-1.40(\mathrm{~m}, 4 \mathrm{H}), 1.30(\mathrm{~s}, 6 \mathrm{H})$, $1.25(\mathrm{~s}, 6 \mathrm{H}), 1.12-1.07(\mathrm{~m}, 9 \mathrm{H}), 0.90(\mathrm{t}, 9 \mathrm{H}, J=7.3 \mathrm{~Hz}) .{ }^{13} \mathrm{C}$ NMR $\left(100 \mathrm{MHz}, \mathrm{CDCl}_{3}\right) \delta 158.9,152.6,150.2,149.7,146.4,137.4$, 136.2, 135.6, 135.1, 134.7, 132.8, 132.3, 131.7, 131.3, 130.8, 130.1, $129.1,128.1,128.0,127.8,124.8,122.5,118.9,117.7,116.9,114.9$, $113.8,110.9,89.1,88.9,73.2,69.7,66.8,51.0,30.3,30.3,28.6$, $18.2,17.4,16.1,13.6,13.0,12.8,11.6,10.8,10.7,10.6$. MALDITOF-MS calcd for $[\mathrm{M}]^{+} 1439.7$, found 1440.0 .

Compound 10b. Compound 8 (0.042 mmol, $50.0 \mathrm{mg})$ and 4-(1aza-7,10-dioxa-4,13-dithiacyclopentadecyl)benzaldehyde $(0.05 \mathrm{mmol}$, $18 \mathrm{mg}$ ) were refluxed in a mixture of benzene $(40.0 \mathrm{~mL})$, glacial acetic acid $(0.5 \mathrm{~mL})$, and piperidine $(0.5 \mathrm{~mL})$. The procedure followed was essentially identical to that for compound 9a. The green colored fraction was collected $(15.0 \mathrm{mg}, 30 \%)$. ${ }^{1} \mathrm{H}$ NMR (400 $\left.\mathrm{MHz}, \mathrm{CDCl}_{3}\right) \delta 7.67-7.60(\mathrm{~m}, 4 \mathrm{H}), 7.54-7.43(\mathrm{~m}, 9 \mathrm{H}), 7.29-7.21$ $(\mathrm{m}, 4 \mathrm{H}), 7.16-7.12(\mathrm{~m}, 3 \mathrm{H}), 6.85(\mathrm{~d}, 4 \mathrm{H}, J=8.4 \mathrm{~Hz}), 6.60(\mathrm{~d}$, $2 \mathrm{H}, J=15.9 \mathrm{~Hz}), 3.90(\mathrm{t}, 4 \mathrm{H}, J=6.9 \mathrm{~Hz}), 3.79-3.68(\mathrm{~m}, 4 \mathrm{H})$, $3.63-3.51(\mathrm{~m}, 8 \mathrm{H}), 2.86-2.79(\mathrm{~m}, 4 \mathrm{H}), 2.74-2.68(\mathrm{~m}, 4 \mathrm{H})$, $2.59-2.54(\mathrm{~m}, 4 \mathrm{H}), 2.50(\mathrm{~s}, 3 \mathrm{H}), 2.18-2.09(\mathrm{~m}, 2 \mathrm{H}), 1.76-1.68$ $(\mathrm{m}, 4 \mathrm{H}), 1.45-1.39(\mathrm{~m}, 4 \mathrm{H}), 1.30(\mathrm{~s}, 6 \mathrm{H}), 1.25(\mathrm{~s}, 6 \mathrm{H}), 1.14-1.07$ $(\mathrm{m}, 9 \mathrm{H}), 0.90(\mathrm{t}, 9 \mathrm{H}, J=7.3 \mathrm{~Hz}) .{ }^{13} \mathrm{C}$ NMR $(100 \mathrm{MHz}, \mathrm{CDCl} 3)$ $\delta 156.9,152.3,151.2,149.7,146.4,137.3,136.3,135.3,135.1$, 134.7, 132.5, 132.3, 131.7, 131.3, 130.8, 130.1, 129.6, 128.1, 128.0, $127.8,125.8,122.7,118.9,117.7,116.9,114.9,113.8,110.9,89.1$, 88.9, 73.2, 69.7, 66.8, 51.0, 30.3, 30.3, 28.6, 18.2, 17.4, 16.1, 13.6, 13.0, 12.8, 11.6, 10.8, 10.7, 10.7. MALDI-TOF-MS calcd for [M $-\mathrm{H}]^{+}$1538.7, found 1538.6.

Acknowledgment. The authors gratefully acknowledge support from TUBITAK and TUBA. R.G. thanks TUBITAK for a graduate scholarship.

Supporting Information Available: ${ }^{1} \mathrm{H}$ and ${ }^{13} \mathrm{C}$ NMR spectra, additional absorbance and emission spectra, binding data, mass spectra, and energy-minimized structures. This material is available free of charge via the Internet at http://pubs.acs.org.

JA902584A

(17) Ishikawa, J. Bull. Chem. Soc. Jpn. 1995, 68, 3071-3076. 